\title{
Low back pain, anthropometric indexes and range of motion of rural workers
}

\author{
Dor lombar, índices antropométricos e flexibilidade em trabalhadores rurais
}

Patrik Nepomuceno ${ }^{1}$, Luíza Müller Schmidt ${ }^{1}$, Marcelo Henrique Glänzel', Miriam Beatrís Reckziegel ${ }^{2}$, Hildegard Hedwig Pohl',3, Éboni Marília Reuter ${ }^{1}$

DOI 10.5935/2595-0118.20190022

\section{ABSTRACT}

BACKGROUND AND OBJECTIVES: This study is necessary considering the expressive number of rural workers that are not assisted by a health professional despite the presence of musculoskeletal changes such as low back pain. Thus, the objective was to check if there is a relationship among low back pain levels, anthropometric measures and range of motion of rural workers. METHODS: A cross-sectional study with rural workers that used the visual analog scale to measure low back pain. The data on body mass index, fat percentage, waist circumference, waisthip ratio and visceral fat area were obtained, as well as the assessment of posterior chain range of motion.

RESULTS: Fifty-five rural workers were evaluated, with a predominance of women and married. Of the subjects evaluated, $37(67.3 \%)$ reported low back pain, with an average pain of 3.4 \pm 2.7 . More than half of the sample presented values of body mass index, fat percentage, waist circumference and waist-hip ratio considered undesirable. Those with pain had higher values of body mass index and visceral fat area.

CONCLUSION: Rural workers with low back pain presented higher values of body mass index and visceral fat area, as well as those with an inadequate range of motion in the same region who had higher values of visceral fat area and pain. It is also possible to infer that there is an association between the values of body mass index and visceral fat area with the level of pain, just as the waisthip ratio is associated with the levels of the range of motion.

Keywords: Anthropometry, Farmers, Low back pain, Range of motion.

Patrik Nepomuceno - (Dhttps://orcid.org/0000-0001-8753-6200;

Luíza Müller Schmidt - (D https://orcid.org/0000-0003-3010-0873;

Marcelo Henrique Glänzel - (Dhttps://orcid.org/0000-0002-0426-3321;

Miriam Beatrís Reckziegel - (Dhttps://orcid.org/0000-0001-5854-3153;

Hildegard Hedwig Pohl - Dhttps://orcid.org/0000-0002-7545-4862;

Éboni Marília Reuter - Dhttps://orcid.org/0000-0002-0470-2910.

1. Universidade de Santa Cruz do Sul, Departamento de Educação Física e Saúde, Curso de Fisioterapia, Santa Cruz do Sul, RS, Brasil.

2. Universidade de Santa Cruz do Sul, Departamento de Educação Física e Saúde, Curso de Educação Física, Santa Cruz do Sul, RS, Brasil.

3. Universidade de Santa Cruz do Sul, Departamento de Educação Física e Saúde, Programa de Pós-Graduaçáo em Promoçáo da Saúde, Santa Cruz do Sul, RS, Brasil.

Submitted on November 08, 2018.

Accepted for publication on February 18, 2019.

Conflict of interests: none - Sponsoring sources: none.

Correspondence to:

Avenida Independência, 2293 - Universitário

96815-900 Santa Cruz do Sul, RS, Brasil.

E-mail: patrik.np@hotmail.com

(C) Sociedade Brasileira para o Estudo da Dor

\section{RESUMO}

JUSTIFICATIVA E OBJETIVOS: O estudo justifica-se pelo expressivo contingente de trabalhadores rurais que não são acompanhados quanto à saúde, ao mesmo tempo que apresentam alteraçôes musculoesqueléticas como dor lombar. Dessa forma, o objetivo foi verificar se há relação entre a dor lombar, medidas antropométricas e níveis de flexibilidade de trabalhadores rurais. MÉTODOS: Trata-se de um estudo transversal com trabalhadores rurais que utilizou a escala analógica visual para mensurar a dor lombar. Foram obtidas as medidas de índice de massa corporal, percentual de gordura, circunferência da cintura, relação cintura-quadril e área de gordura visceral, além da aferição da flexibilidade de cadeia posterior.

RESULTADOS: Foram avaliados 55 trabalhadores rurais, com predomínio do sexo feminino e casados. Dos sujeitos avaliados 37 (67,3\%) referiram queixas de dor lombar, sendo a pontuação média de dor de 3,4 2,7. Mais da metade da amostra apresentava valores de índice de massa corporal, percentual de gordura, circunferência da cintura e relação cintura-quadril classificados em categorias indesejáveis. Aqueles com dor apresentaram valores de índice de massa corporal e área de gordura visceral superiores.

CONCLUSÁO: Os trabalhadores rurais com dor lombar apresentaram valores de índice de massa corporal e área de gordura visceral maiores, assim como aqueles com flexibilidade inadequada na mesma região apresentam valores maiores de área de gordura visceral e dor. Também é possível inferir que há associação entre os valores de índice de massa corporal e área de gordura visceral com o nível de dor, bem como a relação cintura-quadril se associa aos níveis de flexibilidade.

Descritores: Agricultores, Amplitude de movimento, Antropometria, Dor lombar.

\section{INTRODUCTION}

Worker's health has been highlighted in research in the area of collective health, a fact that is related to the incidence of health problems arising from work activity. However, in some populations, these issues need to be addressed in-depth, as is the case of rural workers ${ }^{1}$. These workers present more health problems and diseases when compared to workers in the urban area, not to mention their difficulty in accessing health services ${ }^{2}$.

Farmers often perform activities that require intense physical effort leading to frequent musculoskeletal disorders. As a consequence, they refer to pain and discomfort that interfere with their daily activities. Among the main discomforts identified in these workers is low back pain (LBP). LBP can occur due to 
several factors, such as the reduction of the flexibility of the posterior muscle chain related to workload and lack of actions to prevent injuries, and it may also be connected to obesity. Estimates indicate that from 60 to $80 \%$ of the general population will have low back pain at some point in life ${ }^{1}$.

Such disorders in the spine, which are expressed in pain, lead to the impairment of work activities and postural changes. These workers may have high-intensity pain, which associated with musculoskeletal disorders cause changes in postural stability. In addition, overweight is frequent in this population, which can aggravate their condition. The physical overload during the work activity may favor the onset of LBP and decrease the flexibility of this population. Thus, it is essential to detect these changes to develop actions to prevent related disorders ${ }^{2}$.

Considering that Brazil has a significant number of workers in this sector whose health needs are not monitored, it is evident the importance of knowing their illness profile.

In this context, the present study is justified since it addresses the painful symptoms, referred to as common in rural workers, trying to identify the contributing elements associated with physical fitness. It is known that due to the characteristics of the rural work, high prevalence of LBP is common, reaching $98 \%$, but there is still a gap to be filled by research on this subject in the population. Also, the exponential increase in non-communicable chronic diseases in rural areas, especially obesity, has been described ${ }^{1,3}$. Therefore, the objective was to check if there is a relationship between LBP, anthropometric measures and levels of flexibility of rural workers.

\section{METHODS}

It is a cross-sectional retrospective study ${ }^{4}$ conducted with rural workers from Santa Cruz do Sul and municipalities of the Regional Development Council of the Rio Pardo Valley (COREDE-VRP). It was considered $\alpha$ (two-sided) 0.05 and $80 \%$ power to estimate the statistical power. Thus, with 55 workers it was possible to reach the effect magnitude of $0.45^{4}$. The sample size was calculated in the $\mathrm{G}^{*}$ Power software. The sample was selected by external seminars to introduce the project, and the subjects were invited to participate in the study.

The present study is part of the research "Screening of risk factors related to overweight in workers of the agroindustry using new analytical and health information technologies - Phase III" developed at the University of Santa Cruz do Sul. The age of the selected subjects ranged from 18 to 65 years, who work in rural areas and who signed the Free and Informed Consent Term (FICT). The exclusion criteria were individuals who were unable to complete all the tests or who had already undergone a surgical procedure in the spine.

A self-reported questionnaire on sociodemographic and lifestyle data was applied to characterize the sample. The workers answered questions about gender (female/male), age (in years), socioeconomic class (Brazilian Business Association criteria), marital status (married/other), domestic journey (less than $2 \mathrm{~h}$ and more than $2 \mathrm{~h}$ ) time of activity in the area (in years), hours of work per day, number of children, predominant posture at work (standing, sitting, alternating) and physical activity practice (yes/no).

LBP was measured by the visual analog scale (VAS). Individuals were informed that zero meant no pain and 10 would be the maximum pain. They referred the corresponding value looking at the scale. The results were classified as "no pain" (zero), "mild to moderate pain" (1 to 5$)$, and "moderate to severe pain" (6 to 10$)^{5}$.

The data considered for the anthropometric evaluation was the total obesity indexes such as body mass index (BMI) and percentage of fat $(\% \mathrm{G})$, and fat location such as waist circumference (WC), waist-hip ratio (WHR) and area of visceral fat (AVF).

The weight and height were obtained in an analog scale with a stadiometer to calculate the BMI $\left(\mathrm{kg} / \mathrm{m}^{2}\right)$, being classified according to the categories of the World Health Organization ${ }^{6}$ and later dichotomized in "recommended range" and "overweight." The \%G of seven skinfolds, obtained with the Lange caliper, and all the measurements taken in the right hemisphere, and calculated by the Jackson and Pollock equation, followed by the Siri equation, was classified using the proposal by Pollock and Wilmore ${ }^{7}$. The results "excellent", "good" and "above average" were considered "adequate", and "average", "below average", "bad" and "very bad", as "inadequate".

The WC was obtained with an anthropometric tape at the midpoint between the last rib and the iliac crest. It was classified according to Lean, Han and Morrison ${ }^{8}$ as "normal" considered to be "adequate" and "increased risk" and "high risk" as "inadequate". The WHR was calculated by the ratio between the WC and the hip ratio, obtaining the hip circumference of the major trochanter of the femur, was classified according to Heyward" in "low risk" as "adequate" and "moderate risk", "high risk" and "very high risk" considered "inadequate". The AVF was obtained by bioimpedance analysis (InBody $720^{\circ}$ ) and expressed in $\mathrm{cm}^{3}$ and classified according to Pitanga et al. ${ }^{10}$ as "normal" and "high".

The flexibility was measured in $\mathrm{cm}$ with the sit and reach test using a Wells Bench, with three maneuvers performed and considered the best result. It was classified according to Wells and Dillon ${ }^{11}$ as "weak", "regular", "medium" classified as "inadequate" and "good" and "very good" as "suitable".

This study was approved by the Ethics Committee of the institution under opinion number 2.349.234/2017.

\section{Statistical analysis}

The results were presented in tables and expressed by the mean and standard deviation for numerical data, and frequency and percentage for categorical data, and analyzed by the SPSS Statistics software. The Shapiro-Wilk test was used to check data normality. Pearson's (parametric variables) and Spearman's tests (non-parametric variables) were used for the correlation analysis. The comparison of means between the groups was checked by the Student's $t$-test for independent samples, and ANOVA with Hochberg's post-hoc GT2 (parametric variables) and Mann-Whitney and Kruskal-Wallis U (non-parametric variables). For the categorical variables, the Chi-square test was used considering $\mathrm{p}<0.05$. 


\section{RESULTS}

Fifty-five individuals with mean age of $48.4 \pm 12.2$ years were evaluated, of which 30 (54.5\%) were female, mostly married (76.4\%) with children (85.5\%) and C1 and C2 socioeconomic status $(56.4 \%)$. The average years working in agriculture was $26.64 \pm 15.88$ years. Regarding household chores, the majority of the sample reported less than $2 \mathrm{~h}$ daily $(72.2 \%)$, with no relation between household chores and pain. Also, no differences were observed between gender and household chores time $(\mathrm{p}=0.269)$, although only women have reported dedicating from 4 to 6 hours for such activities $(n=5)$.

In the comparison of sociodemographic and lifestyle variables in the groups with pain, no differences were found for gender, age, marital status, domestic journey, activity time, hours of work per day, number of children and practice of physical activity. However, it is possible to observe that individuals of the B socioeconomic class had more pain than those belonging to class C. In addition, individuals with higher pain intensity perform their work activities alternating between standing and sitting (Table 1).
When asked about LBP, 37 (67.3\%) complained of pain in this region with a mean pain score in the VAS of $3.4 \pm 2.7$. Regarding the variables evaluated, more than half of the sample had BMI values. \%G, WC and WHR were classified as undesirable categories (Table 2).

When comparing the averages of the anthropometric variables and the flexibility of the individuals without LBP with mild to moderate and moderate to severe pain, it was identified that

Table 2. Characterization of subjects regarding the anthropometric and flexibility variables

\begin{tabular}{lcc}
\hline Variables & Adequate $\mathrm{n}(\%)$ & Inadequate $\mathrm{n}(\%)$ \\
\hline BMI & $19(34.5)$ & $36(65.5)$ \\
$\% \mathrm{G}$ & $24(43.6)$ & $31(56.4)$ \\
WC & $25(45.5)$ & $30(54.5)$ \\
WHR & $10(18.2)$ & $45(81.8)$ \\
AVF & $29(52.7)$ & $26(47.3)$ \\
SRT & $32(58.2)$ & $23(41.8)$ \\
\hline
\end{tabular}

$\mathrm{BMI}=$ body mass index; $\% \mathrm{G}=$ percentage of fat; $\mathrm{WC}=$ waist circumference; $\mathrm{WHR}=$ waist-to-hip ratio; $\mathrm{AVF}=$ area of visceral fat; SRT = sit and reach test.

Table 1. Characterization of the sample regarding sociodemographic data and lifestyle

\begin{tabular}{|c|c|c|c|c|}
\hline \multirow[t]{2}{*}{ Variables } & \multicolumn{3}{|c|}{ Low back pain } & \multirow[t]{2}{*}{$p$-value } \\
\hline & $\begin{array}{l}\text { Without pain } \\
\qquad(n=18)\end{array}$ & $\begin{array}{l}\text { Mild to moderate } \\
\qquad(\mathrm{n}=24)\end{array}$ & $\begin{array}{l}\text { Moderate to intense } \\
\qquad(\mathrm{n}=13)\end{array}$ & \\
\hline \multicolumn{5}{|l|}{ Gender* } \\
\hline Female & $8(32.0)$ & $12(48.0)$ & $5(20.0)$ & $0.793^{\mathrm{a}}$ \\
\hline Male & $10(33.3)$ & $12(40.0)$ & $8(26.7)$ & \\
\hline $\operatorname{Age}^{\star \star}$ & $49.89(11.62)$ & $46.96(13.04)$ & $48.92(12.20)$ & $0.739^{b}$ \\
\hline $\mathrm{B}$ & $2(9.5)$ & $14(66.7)$ & $5(23.8)$ & $0.005^{a}$ \\
\hline $\mathrm{C}$ & $15(48.4)$ & $8(25.8)$ & $8(25.8)$ & \\
\hline \multicolumn{5}{|l|}{ Marital status* } \\
\hline Married & $13(31.0)$ & $18(42.9)$ & $11(26.2)$ & $0.710^{\mathrm{a}}$ \\
\hline More than 2 hours & 5 (33.3) & $5(33.3)$ & $5(33.3)$ & \\
\hline Time of activity ${ }^{\star \star}$ & $21.17(13.80)$ & $29.75(16.48)$ & $28.46(16.65)$ & $0.302^{\mathrm{b}}$ \\
\hline Working hours/day ${ }^{\star \star}$ & $8.67(2.50)$ & $9.33(2.26)$ & $10.46(1.85)$ & $0.067^{c}$ \\
\hline \multicolumn{5}{|l|}{ Children* } \\
\hline Yes & 15 (31.9) & $21(44.7)$ & $11(23.4)$ & $0.926^{a}$ \\
\hline No & $3(37.5)$ & $3(37.5)$ & $2(25.0)$ & \\
\hline Number of children ${ }^{\star *}$ & $2.07(0.88)$ & $1.81(0.93)$ & $2.36(0.81)$ & $0.187^{\circ}$ \\
\hline \multicolumn{5}{|l|}{ Predominant posture $^{*}$} \\
\hline Standing & $15(40.5)$ & $17(45.9)$ & $5(13.5)$ & $0.028^{a}$ \\
\hline
\end{tabular}


those with pain had higher BMI and AVF values, and the values of these variables increased with the referred pain intensity. In multiple comparisons, it was identified an AVF and BMI difference between the groups without pain and moderate to severe pain $(\mathrm{p}=0.031 ; \mathrm{p}=0.046$, respectively) (Table 3 ).

When comparing the anthropometric and VAS values considering the categories of flexibility, the individuals with inadequate levels of flexibility had higher AVF values $(\mathrm{p}=0.035)$ and LBP $(\mathrm{p}=0.014)$ (Table 4).

Moreover, it was observed an association between the VAS for the lumbar region and the BMI variables $(r=0.304 ; \mathrm{p}=0.024)$ and AVF $(r=0.314 ; p=0.020)$. Thus, one can infer that the higher the BMI and AVF, the higher the referred pain score. We also identified a weak and inverse association between the WHR and the flexibility that involves the lumbar region, the higher the WHR, the lower the SRT values $(r=-0.276 ; \mathrm{p}=0.042)$.

When comparing the variables for age, it was observed that there was no difference in BMI values, AVF, SRT, and VAS, indicating that age does not influence pain and flexibility. However, values of central adiposity, evaluated by WC and WHR increase progressively with age, as well as total obesity by \%G. In multiple comparisons, differences between 18 and 39 years and 40 and 59 years were observed for $\% \mathrm{G}(\mathrm{p}=0.025)$; between $40-59$ and 60-65 years for WHR ( $\mathrm{p}=0.015)$ and between 18-39 and 60-65 years for WC ( $\mathrm{p}=0.026)$ and WHR (0.004) (Table 5).

Table 3. Comparison of means between groups of pain

\begin{tabular}{|c|c|c|c|c|}
\hline \multirow[t]{2}{*}{ Variables } & \multicolumn{3}{|c|}{ Low back pain } & \multirow[t]{2}{*}{$p$-value } \\
\hline & $\begin{array}{l}\text { Without pain } \\
\quad(n=18)\end{array}$ & $\begin{array}{l}\text { Mild to mo- } \\
\text { derate } \\
(n=24)\end{array}$ & $\begin{array}{l}\text { Moderate to } \\
\text { intense } \\
(n=13)\end{array}$ & \\
\hline BMI & $25.94(2.78)$ & 27.18 (5.92) & 30.97 (6.02) & $0.035^{a}$ \\
\hline$\% G$ & $25.26(5.84)$ & $25.48(7.85)$ & 29.26 (5.83) & $0.209^{b}$ \\
\hline WC & $86.86(9.24)$ & 87.85 (10.08) & $93.72(13.43)$ & $0.182^{\mathrm{b}}$ \\
\hline WHR & $0.87(0.08)$ & $0.86(0.08)$ & $0.86(0.10)$ & $0.988^{b}$ \\
\hline AVF & $86.91(29.15)$ & $98.01(43.00)$ & $\begin{array}{l}124.24 \\
(41.46)\end{array}$ & $0.034^{b}$ \\
\hline SRT & $28.09(7.83)$ & $26.72(9.70)$ & 23.53 (7.26) & $0.343^{b}$ \\
\hline
\end{tabular}

$\mathrm{BMI}=$ body mass index; $\% \mathrm{G}=$ percentage of fat; $\mathrm{WC}=$ waist circumference; WHR = waist-to-hip ratio; AVF = area of visceral fat; SRT = sit and reach test; ${ }^{\text {a }}$ Kruskal-Wallis test; ${ }^{\text {b }}$ ANOVA with Hochberg post-hoc GT2.

Table 4. Comparison of means between groups of flexibility

\begin{tabular}{lccc}
\hline Variables & \multicolumn{2}{c}{ Flexibility } & p-value \\
& $\begin{array}{c}\text { Adequate } \\
(\mathrm{n}=32)\end{array}$ & $\begin{array}{c}\text { Inadequate } \\
(\mathrm{n}=23)\end{array}$ & \\
\hline Age & $45.39(11.16)$ & $50.53(12.69)$ & $0.125^{\mathrm{b}}$ \\
BMI & $26.40(3.42)$ & $29.44(7.03)$ & $0.162^{\mathrm{a}}$ \\
$\% G$ & $25.60(6.82)$ & $27.28(7.00)$ & $0.378^{\mathrm{b}}$ \\
WC & $86.90(8.17)$ & $91.72(13.44)$ & $0.136^{\mathrm{b}}$ \\
WHR & $0.87(0.09)$ & $0.86(0.08)$ & $0.945^{\mathrm{b}}$ \\
AVF & $90.89(33.54)$ & $114.06(45.90)$ & $0.035^{\mathrm{b}}$ \\
VAS & $2.63(2.47)$ & $4.35(2.64)$ & $0.014^{\mathrm{a}}$
\end{tabular}

$\mathrm{BMI}=$ body mass index; $\% \mathrm{G}=$ percentage of fat; $\mathrm{WC}=$ waist circumference; WHR = waist-to-hip ratio; AVF = area of visceral fat; VAS = visual analog scale; a Mann-Whitney U test; ${ }^{\text {b }}$ Student's $t$-test.
Table 5. Comparison of means between age groups

\begin{tabular}{lcccc}
\hline Variables & \multicolumn{3}{c}{ Ages } & p-value \\
& $\begin{array}{c}18-39 \text { years } \\
(\mathrm{n}=12)\end{array}$ & $\begin{array}{c}40-59 \text { years } \\
(\mathrm{n}=32)\end{array}$ & $\begin{array}{c}60-65 \text { years } \\
(\mathrm{n}=11)\end{array}$ & \\
\hline BMI & $25.21(3.47)$ & $28.30(5.77)$ & $28.53(5.61)$ & $0.248^{\mathrm{a}}$ \\
$\% \mathrm{G}$ & $21.65(5.66)$ & $27.71(7.05)$ & $27.27(5.75)$ & $0.027^{\mathrm{b}}$ \\
WC & $83.46(11.58)$ & $88.79(9.95)$ & $95.21(10.08)$ & $0.031^{\mathrm{b}}$ \\
WHR & $0.82(0.82)$ & $0.86(0.08)$ & $0.94(0.06)$ & $0.003^{\mathrm{b}}$ \\
AVF & $83.41(25.38)$ & $103.56(43.03)$ & $110.64(43.56)$ & $0.225^{\mathrm{b}}$ \\
SRT & $28.32(7.03)$ & $26.87(8.55)$ & $23.02(10.05)$ & $0.308^{\mathrm{b}}$ \\
VAS & $3.25(2.67)$ & $3.28(2.78)$ & $3.64(2.50)$ & $0.888^{\mathrm{a}}$ \\
\hline
\end{tabular}

$\mathrm{BMI}=$ body mass index; $\% \mathrm{G}=$ percentage of fat; $\mathrm{WC}=$ waist circumference WHR = waist-to-hip ratio; $A V F=$ area of visceral fat $S \mathrm{SRT}=$ sit and reach test; VAS = visual analog scale; ${ }^{\text {a }}$ Kruskal-Wallis test; ${ }^{\mathrm{b}}$ ANOVA with Hochberg post hocGT2.

\section{DISCUSSION}

Agriculture is characterized by heavy manual labor. Farmers need to handle a considerable amount of weight to transport their materials and products. During this activity, they adopt inappropriate postures that can damage the tissues, especially muscles and joints which favor the onset of $\mathrm{LBP}^{12}$. LBP may be associated with radiated pain or pain in the lower limbs, especially in rural workers who spend long hours standing to do their job ${ }^{13}$. In the present study, it was observed that individuals with high pain values performed their activities alternating between standing and sitting, which may be related to an attempt to adapt to the work routine due to the pain.

Although agricultural activity is considered as a risk factor for the development of LBP, its influence on the health of the worker is poorly explored, especially in the painful situations ${ }^{14}$. The present results show that both BMI and AVF are related to pain and its intensity in rural workers. It is also possible to observe that pain, AVF and WHR are associated with flexibility, which can be explained by a possible overload in the lumbar spine and changes in the center of gravity.

A study by Briggs et al. ${ }^{15}$ observed that subjects with increased WC had significantly higher pain values $(\mathrm{OR}=2.39$; CI: $1.09-5.21)$, a different result from the present study. However, it was also observed that subjects classified by BMI with overweight or obesity showed a higher frequency of LBP and systemic inflammation that may contribute to the aggravation of pain.

In a large-scale study by Hashimoto et al. ${ }^{16}$ conducted with Japanese men found that the chance of LBP is greater in overweight individuals when compared to those who have desirable BMI results, highlighting the need for $\mathrm{BMI}$ control, both to prevent and treat LBP. A national survey in the United States ${ }^{17}$ observed that individuals with overweight or obesity, evaluated by BMI, had great chances of having LBP $(\mathrm{OR}=1.21$; CI: 1.11-1.32 and $\mathrm{OR}=1.55$; CI: $1.44-1.67$, respectively). This survey found that white men and women were at increased risk of developing LBP. Considering the characteristics of our region, this could be a justification for the high prevalence of pain observed in this study. The findings described corroborate those found in the present 
study. Thus, one can infer that overweight is related to the increased chance of developing LBP.

lizuka et al. ${ }^{18}$ analyzed the prevalence of chronic non-specific LBP and related factors in middle-aged and elderly individuals and did not identify a relationship between BMI and the presence of pain $(\mathrm{p}=0.422)$. This result is the opposite of that observed in the present study and may be due to the low prevalence of LBP $(24.8 \%)$ in the sample. However, it has pointed out that smoking and the quality of life is related to LBP $(\mathrm{p}=0.021$; $\mathrm{p}=0.016$, respectively). The authors do not have a justification for such results.

Su et al. ${ }^{19}$ studied the association between BMI and prevalence, severity and frequency of LBP. When comparing the frequency of LBP with the BMI classification, it was observed that the frequency is higher $(p<0.05)$ in overweight and obesity, as well as in severe and morbid obesity $(\mathrm{p}<0.01)$ when compared to the group with normal weight or low weight. Therefore, these data corroborate those of this study considering that the higher the BMI and AVF, the greater the pain intensity. The authors did not identify a relationship between BMI and the severity or frequency of low back pain episodes.

Rahmani et al. ${ }^{20}$ used ultrasonography to check the dimensions of the multifidus muscle in adolescents with and without LBP and found an association between muscle size and BMI, and this is a possible explanation for the high prevalence of LBP in overweight individuals observed in the present study. Besides, it was observed that all muscle measures correlate inversely with pain intensity and functional disability, suggesting that the smaller the dimensions, the greater the pain and the disability.

In a study with rural workers from a region of Santa Catarina ${ }^{1 .}$ the prevalence of $98.3 \%$ of LBP was found with an average pain on the VAS of $5.89 \pm 2.49$, being more intense in women (mean: $6.14 \pm 2.45$. There was a relationship between pain and SRT $(r=-$ $0.42 ; \mathrm{p}<0.01)$. These data are in agreement with the present results considering that individuals with inadequate flexibility had higher pain values.

Silva et al..$^{21}$ found similar results with rural workers in the Vale do Rio Pardo. The individuals with high intensity of pain had lower levels of flexibility and considerable postural changes. LBP is common in Thai rubber farmers. Udom, Janwantanakul and Kanlayanaphotporn ${ }^{22}$ found a high prevalence of LBP (55.7\%) with high intensity, identifying a relationship between BMI and pain $(\mathrm{p}=0.048)$ and corroborating the present study. So, it is possible to infer that BMI is an important predictor of LBP in different populations. Several studies have observed that there is an association between anthropometric markers, such as weight, $\mathrm{BMI}, \mathrm{WC}$, and LBP, confirming that the increase in fat is a risk factor for the development of LBP23,24.

Workers from several sectors are exposed to the reduction of elements of physical fitness according to the work performed. Nepomuceno et al. ${ }^{25}$ analyzed the profile of industrial workers and detected prevalence of pain, reduced flexibility and anthropometric changes, reinforcing the results found in the present study. They also observed a tendency in the association between flexibility and the presence of pain. Therefore, flexibility may influence pain.
Paz et al. ${ }^{26}$ identified that the anthropometric variables were not related to lumbar functional disability. Even so, the study sample was considered relatively healthy, which may have contributed to this result. It was highlighted that lumbar flexibility, assessed by the SRT, presented greater association with disability.

Obesity can play a role not only on pain and flexibility but also in muscular endurance. Ummunah, Ibkunle and Ezeakunne ${ }^{27}$ identified an inverse relationship between BMI and hip circumference with the maximum sustaining time of isometric contraction. That means that the higher the fat, the shorter the maintenance time of muscle contraction, and these results may be important in explaining LBP in overweight individuals.

It was considered that the sample size might have been a limiting factor of the study, in part due to the difficulty of access of this population historically unassisted. However, this study brings important considerations about the health of the rural population and also for the planning of actions that promote health and the prevention of diseases related to LBP. Moreover, it was found that individuals with a higher socioeconomic class had more pain. Nonetheless, the mechanisms that associate this variable with pain remain unknown.

\section{CONCLUSION}

The present study showed that rural workers with LBP had higher BMI and AVF values, as well as those with inadequate flexibility in the same region had higher values of AVF and pain. It is also possible to infer that there is an association between the values of BMI and AVF with the level of pain, and WHR is associated with levels of flexibility.

\section{ACKNOWLEDGMENTS}

To Professor Tania Cristina Malezan Fleig from the Physiotherapy course of the University of Santa Cruz do Sul for the valuable contribution in the elaboration of this research project and manuscript.

\section{REFERENCES}

1. Silva MR, Ferretti F, Lutinski JA. Dor lombar, flexibilidade muscular e relação com o nível de atividade física de trabalhadores rurais. Saúde Debate. 2017;41(112):183-94.

2. Befort CA, Nazir N, Perri MG. Prevalence of obesity among adults from rural and urban areas of the United States: findings from NHANES (2005-2008). J Rural Health. 2012;28(4):392-7.

3. O'Sullivan D, Cunningham C, Blake C. Low back pain among Irish farmers. Occup Med. 2009;59(1):59-61.

4. Hulley SB, Cummings SR, Browner WS, Grady DG, Newman TB. Delineando a pesquisa clínica. 4a ed. Porto Alegre: Artmed; 2015. 386p.

5. Sociedade Brasileira para Estudo da Dor [Internet]. 50 Sinal Vital. 2009. [cited 2018 May 17]. Available from: http://www.sbed.org.br/materias.php?cd_secao=65.

6. World Health Organization [Internet]. BMI classification. 2006. [cited 2018 May 17]. Available from: http://apps.who.int/bmi/index.jsp?introPage=intro_3.html.

7. Pollock M, Wilmore J. Exercícios na saúde e na doença: avaliaçăo e prescrição para prevençấo e avaliaçăo. Rio de Janeiro: Medsi; 1993.

8. Lean ME, Han TS, Morrison CE. Waist circumference as a measure for indicating need for weight management. BMJ. 1995;311(6998):158-61.

9. Heyward VH. Avaliaçấo Física e Prescriçấo de Exercício: técnicas avançadas. $6^{\text {th }}$ ed. Porto Alegre: Artmed; 2013. 485p.

10. Pitanga CP, Pitanga FJ, Gabriel RE, Moreira MH. Associação entre o nível de atividade física e a área de gordura visceral em mulheres pós-menopáusicas. Rev Bras Med Esporte. 2014;20(4):252-4. 
11. Wells KF, Dillon EK. The sit and reach: a test of back and leg flexibility. Res Q Exerc Sport. 1952;23:115-8.

12. Keawduangdee P, Puntumetakul R, Swangnetr M, Laohasiriwong W, Settheetham D, Yamauchi J, et al. Prevalence of low back pain and associated factors among farmers during the rice transplanting process. J Phys Ther Sci. 2015;27(7):2239-45.

13. Essien SK, Trask C, Dosman J, Bath B. Investigating the association between lower extremity and low back symptoms among Saskatchewan farmers using the Standardized Nordic Questionnaire. Spine. 2017;42(19):1147-54.

14. Meucci RD, Fassa AG, Faria NM, Fiori NS. Chronic low back pain among tobacco farmers in southern Brazil. Int J Occup Environ Health. 2015;21(1):66-73.

15. Briggs MS, Givens DL, Schmitt LC, Taylor CA. Relations of C-reactive protein and obesity to the prevalence and the odds of reporting low back pain. Arch Phys Med Rehabil. 2013;94(4):745-52.

16. Hashimoto Y, Matsudaira K, Sawada SS, Gando Y, Kawakami R, Sloan RA, et al. Association between objectively measured physical activity and body mass index with low back pain: a large-scale cross-sectional study of Japanese men. BMC Public Health. 2018;18(341):1-8

17. Peng T, Pérez A, Pettee Gabriel K. The association among overweight, obesity, and low back pain in U.S. adults: a Cross-Sectional Study of the 2015 National Health Interview Survey. J Manipulative Physiol Ther. 2018;41(4):294-303.

18. Iizuka Y, Iizuka H, Mieda T, Tsunoda D, Sasaki T, Tajika T, et al. Prevalence of chronic nonspecific low back pain and its associated factors among middle-aged and elderly people: an analysis based on data from a musculoskeletal examination in Japan. Asian Spine J. 2017;11(6):989-97.
19. Su CA, Kusin DJ, Li SQ, Ahn UM, Ahn NU. The association between body mass index and the prevalence, severity, and frequency of low back pain: data from the osteoarthritis initiative. Spine. 2018;43(12):848-52.

20. Rahmani N, Kiani A, Mohseni-Bandpei MA, Abdollahi I. Multifidus muscle size in adolescents with and without back pain using ultrasonography. J Bodyw Mov Ther. 2018;22(1):147-51.

21. Silva RK, Reckziegel MB, Burgos MS, Pohl HH. Dor lombar e sua relação com a flexibilidade e os desvios posturais em trabalhadores rurais de municípios da microrregiāo sul do Vale do Rio Pardo/RS. Fisioter Bras. 2017;18(2):130-9.

22. Udom C, Janwantanakul P, Kanlayanaphotporn R. The prevalence of low back pain and its associated factors in Thai rubber farmers. J Occup Health. 2016;58(6):534-42.

23. Brooks C, Siegler JC, Marshall PWM. Relative abdominal adiposity is associated with chronic low back pain: a preliminary explorative study. BMC Public Health. 2016;16(1):700-8.

24. Heuch I, Heuch I, Hagen K, Zwart JA. A comparison of anthropometric measures for assessing the association between body size and risk of chronic low back pain: the HUNT Study. PLoS One. 2015;10(10):e0151268.

25. Nepomuceno P, Braz CD, Dummel KL, Wendt D, Campos GD, Couto AN, et al Perfil antropométrico e a relaçáo da flexibilidade com a dor e desconforto em trabalhadores da indústria de Santa Cruz do Sul - RS. Cinergis. 2016;17(4):313-8.

26. Paz GA, Maia MF, Santiago FL, Lima VP. Correlaçâo entre incapacidade funciona lombar e índices da aptidão física para a saúde. Saúde em Rev. 2012;12(31):23-30.

27. Ummunah JO, Ibikunle PO, Ezeakunne AC. Relationship between isometric endurance of back extensor muscles and selected anthropometric indices among some Nigerian undergraduates. J Back Musculoskelet Rehabil. 2014;27(3):291-8. 